Steven M. Oberhelman

Healing Manuals from Ottoman and Modern Greece 


\section{Medical Traditions}

Edited by

Alain Touwaide

Scientific Committee

Michael Friedrich, Jost Gippert, Marilena Maniaci, Paolo Odorico, Steve M. Oberhelman, Dominik Wujastyk

\section{Volume 4}




\section{Steven M. Oberhelman}

\section{Healing Manuals}

from Ottoman and Modern Greece

The Medical Recipes of Gymnasios Lauriōtis in Context

\section{DE GRUYTER}


ISBN 978-3-11-066109-5

e-ISBN (PDF) 978-3-11-066443-0

e-ISBN (EPUB) 978-3-11-066123-1

ISSN 2567-6938

Library of Congress Control Number: 2020934511

Bibliographic information published by the Deutsche Nationalbibliothek

The Deutsche Nationalbibliothek lists this publication in the Deutsche Nationalbibliografie;

detailed bibliographic data are available on the Internet at http://dnb.dnb.de.

(c) 2020 Walter de Gruyter GmbH, Berlin/Boston

Cover image: Collage of illustrations in medical treatises from the 1st to the 16th century CE, from Greece and Rome, to the Arabic World and China.

Typesetting: Integra Software Services Pvt. Ltd.

Printing and binding: $\mathrm{CPI}$ books $\mathrm{GmbH}$, Leck

www.degruyter.com 